\title{
ダムコンクリートの压繀強度に及ぼす粗骨材 の影響
}

\author{
梅原秀哲* ·張 剣 ${ }^{* *} \cdot$ 上田 稔*** \\ 吉田弥智****
}

ダムコンクリートのように、粗骨材最大寸法が $150 \mathrm{~mm}$ 程度の粒形の大きな粗骨材を 用いると、ブリージングによって生じる粗骨材下部の空隙により、圧縮強度が低下する. 本研究は、モルタル製の複数のモデル骨材からなるコンクリート供試体を作製し、圧縮 強度試験を行うとともに、有限要素法を用いた解析を行うことにより、骨材の寸法、形 状、個数等が圧縮強度に与える影響を検討し、圧縮強度低下機構を明らかにするもので ある.

Keywords : dam concrete, coarse aggregate, bleeding, compressive strength, finite element method

\section{1. まえがき}

粗骨材がコンクリートの力学的特性に及ぼす影響に関 して、これまでに数多くの研究が行われている. 中でも、 コンクリートの圧縮強度に関しての研究が最も多く、粗 骨材とセメントペーストとの付着が王縮強度に与える影 響を微視的に調べた岩崎ら ${ }^{1)} 、$ 鈴木ら ${ }^{2)}$, 川上ら ${ }^{3)}$, 森野 $ら^{4)}$ の研究, 粗骨材の圧縮強度がコンクリートの圧縮強 度に与える影響を調べた爾見ら ${ }^{5), 6)}$ の研究，モデル骨材 を用いて粗骨材の材質, 表面状態, 形状等がコンクリー トの圧縮破壊機構および圧縮強度に与える影響を調べた 枷場 ${ }^{7), 8)}$, 小阪 $ら^{9)-12)}$ の研究がある.

粗骨材とセメントペーストとの付着を微視的に見る と, 粗骨材とセメントペーストとの界面には $\mathrm{Ca}(\mathrm{OH})_{2}$ の薄膜が存在し, 界面が多孔質であるとそこに $\mathrm{Ca}(\mathrm{OH})_{2}$ がたい積し, 付着強度が低下することが認められている. さらにモデル骨材を用いた研究から，粗骨材とセメント ペーストとに全く付着がなければ，コンクリートの圧縮 強度は粗骨材がほとんどない状態の圧縮強度に等しくな るため, 圧縮強度に与える付着の重要性が指摘されてい る.

また，粗骨材の圧縮強度がモルタルの圧縮強度より小 さい場合には，コンクリートの圧縮強度は粗骨材の圧縮 強度に影響される. モデル骨材を用いて圧縮試験を行う と, まず母材モルタルと粗骨材間にボンドクラック（粗 骨材とモルタルの付着面に沿って発生するひびわれを言 う）が生じる. その後, 粗骨材の中央部及び上下端近傍 の母材モルタル部にほぼ同時に載荷軸方向のひびわれが

\footnotetext{
*正会員 $\mathrm{Ph} . \mathrm{D}$ 名古屋工業大学助教授 工学部社会開発 工学科 ( 4466 名古屋市昭和区御器所町)

**正会員 工修 矢作建設工業（株）

***正会員 工修 名古屋工業大学大学院 工学部社会開発工 学科

**** 正会員 工博 名古屋工業大学長
}

生じ，最後に粗骨材で破壊するこどが明らかにされてい る. 次に, 粗骨材の圧縮強度がモルタルの圧縮強度より 大きい場合には，コンクリートの圧縮強度は粗骨材の圧 縮強度にほとんど影響されない. 母材モルタルと粗骨材 間にボンドクラックが生じた後, ボンドクラックが母材 モルタル部に進展して載荷軸方向のモルタルクラックを 発生させ, その後粗骨材の上下端近傍の母材モルタル部 分が破壊することが明らかにされている.さらにモデル 骨材を用いた研究から，ボンドクラックはモルタルク ラックよりも早期に進展し，ボンドクラックは圧縮強度 の $50 \%$ で，またモルタルクラックは圧縮強度の $70 \%$ で

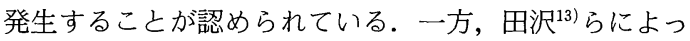
てモデル骨材を用いて，ブリージングによる粗骨材の下 部の空隙が圧縮強度に及ぼす影響が調べられており，同 一ブリージング量ならば寸法の大きな粗骨材の下部の空 隙から，モルタルクラックが進展することが明らかにさ れている。

以上をまとめると, 粗骨材の圧縮強度および粗骨材と セメントペーストとの付着がコンクリートの圧縮強度に 大きく影響し，さらにこの付着はブリージングによって 影響される. したがって，ブリージングによる粗骨材下 部の空隙の程度を把握することが，コンクリートの圧縮 強度を予測する上で最も重要な点であると考えられる.

ところで，これまでの研究はほとんどが $G_{\max }$ (粗骨 材の最大寸法）が $40 \mathrm{~mm}$ 以下についての研究であり， ダムコンクリートなどを対象とした $G_{\max }$ が $150 \mathrm{~mm}$ 程 度の配合ではほとんど行われていない。 また，ダムコン クリートの品質管理手法として圧縮強度試験が行われて いるが， $G_{\max }$ が $40 \mathrm{~mm}$ 以上の配合の場合は，ウェット スクリーニングを行って供試体を作製している．特に骨 材の影響が大きいダムコンクリートにおいてウェットス クリーニングを行うことは, $40 \mathrm{~mm}$ 以上の粗骨材の影 響が全く反映されないため, ウェットスクリーニングさ 

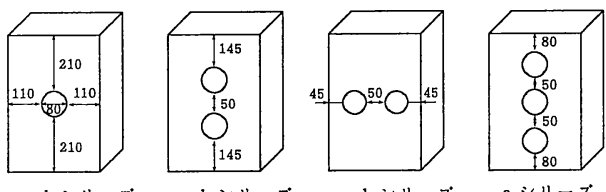

$\mathrm{a} \cdot \mathrm{b}$ シリーズ

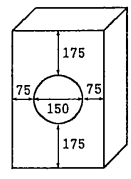

$\mathrm{a}$ ・ b シリーズ

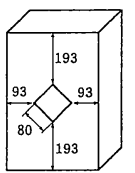

$\mathrm{a} \cdot \mathrm{b}$ シリーズ

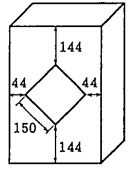

$\mathrm{a} \cdot \mathrm{b}$ シリーズ
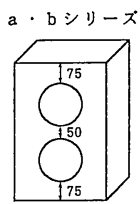

$\mathrm{a} \cdot \mathrm{b}$ シリーズ
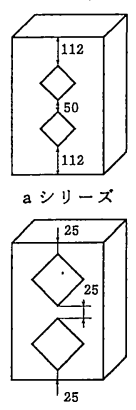

aシリーズ

図一1 供試体の概要

れたコンクリートの品質は, 実際のコンクリートの品質 之相違していると思われる.

そこで, ウェットスクリーニングがコンクリートの圧 縮強度などに及ぼす影響を粗骨材の最大寸法および単位 水量を指標として検討を行った結果， $40 \mathrm{~mm}$ 以上のふ るいでウェットスクリーニングを行うと， $G_{\max }$ が 150 $\mathrm{mm}$ でウェットスクリーニングを行わない場合の圧縮強 度およびコンクリート内部の挙動と類似した傾向を示す が，ふるい目を $25 \mathrm{~mm}$ 以下とすると压縮強度および内 部挙動とも $150 \mathrm{~mm}$ の場合と全く異なる傾向を示すこと が著者らの研究により明らかとなった ${ }^{14)}$ ．そしてその原 因として，ブリージングによって生じる粗骨材下部の空 隙の影響，その中でも特に粒径の大きな粗骨材において 空隙の影響の大きいことが考えられた，さらにこの考察 を検証するために，著者らは母材コンクリートと $G_{\max }$ が $40 \mathrm{~mm}$ 以上のモルタル製の単一モデル骨材からなる モデルコンクリートを作製し，モデル骨材の寸法，形状 および母材コンクリートの単位水量をパラメータとした 圧縮試験を行った ${ }^{15}$. なお, 実際の骨材では骨材品種が 相違する之骨材の材質, 形状や表面状態などが異なるた め, コンクリートの力学的特性に及ぼす骨材の影響を調 ベる場合に，従来から用いられているモデル骨材を用い る方法をここでは採用した．その結果，モデル骨材下部 のブリージングによる空隙がひびわれや圧縮強度に影響 を与え, 特に $80 \mathrm{~mm}$ 以上のモデル骨材でその影響が顕 著となることが明らかとなった．しかし，単一モデル骨 材であるため, 骨材相互の影響が考慮されていないこと

\begin{tabular}{|c|c|c|c|c|c|c|c|c|}
\hline \multirow{2}{*}{$\begin{array}{c}\text { 相骨材の } \\
\text { 敢大寸法 } \\
\quad(\mathrm{mm})\end{array}$} & \multirow{2}{*}{ スランブ } & 空気量 & $\begin{array}{l}\text { 水セメ } \\
\text { シト比 } \\
\mathrm{W} / \mathrm{C}\end{array}$ & $\begin{array}{l}\text { 細骨林 } \\
\text { 率 } \\
\mathrm{s} / \mathrm{a}\end{array}$ & \multicolumn{2}{|r|}{ 単位量 } & \multicolumn{2}{|c|}{$\left(\mathrm{kg} / \mathrm{m}^{3}\right)$} \\
\hline & & (\%) & $\begin{array}{l}\mathrm{W} / \mathrm{C} \\
(\%)\end{array}$ & $\begin{array}{l}\mathrm{s} / \mathrm{a} \\
(\%)\end{array}$ & $\begin{array}{l}\text { 水 } \\
\mathrm{W}\end{array}$ & $\begin{array}{c}\text { セメント } \\
\mathrm{C}\end{array}$ & $\stackrel{\text { 細骨材 }}{S}$ & 柤骨材 \\
\hline 25 & 10 & 1.5 & 70 & 44.5 & 179 & 252 & 808 & 1079 \\
\hline \multicolumn{9}{|c|}{ モデル骨材用モルタル（28日設計強度 } \\
\hline & \multirow{2}{*}{\multicolumn{2}{|c|}{$\begin{array}{c}\text { 水セx } \\
\text { 卢比 } \\
\text { W/C } \\
(96)\end{array}$}} & \multirow{2}{*}{$\begin{array}{c}\text { 砂セメ } \\
\text { ント比 } \\
\text { S/C } \\
(\%)\end{array}$} & \multicolumn{3}{|c|}{ 単位量 } & & \\
\hline & & & & $\begin{array}{l}\text { 水 } \\
W\end{array}$ & $\begin{array}{c}\text { セxント } \\
\mathrm{C}\end{array}$ & $\begin{array}{c}\text { 細骨材 } \\
\mathrm{S}\end{array}$ & & \\
\hline & & 30 & 44.5 & 430 & 1430 & 290 & & \\
\hline
\end{tabular}

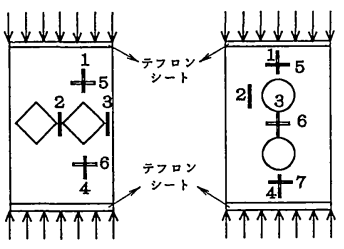

図一2 載荷状況

や，実験結果より複数個のモデル骨材を用いれば，単一 の場合よりも圧縮強度がさらに低下する可能性が示唆さ れたことから, 複数個のモデル骨材を配置して, より実 際に近い実験を行う必要性が生じた.

そこで本研究では， $G_{\max }$ が $80 \mathrm{~mm}$ 以上のモルタル製 の複数のモデル骨材からなるモデルコンクリートを作製 し，モデル骨材の寸法，形状，個数，配置位置および表 面状態を変化させて実験を行うとともに, 有限要素法を 用いた解析を行うことにより，粗骨材下部の空隙による ダムコンクリートの圧縮強度低下機構を解明することを 試みた。

\section{2. 実 験 概 要}

\section{（1）供試体}

図一1に示すように, 中央に高強度のモルタルで作っ た複数のモデル骨材を配置した $50 \times 30 \times 12 \mathrm{~cm}$ の直方体 の供試体を作製した。モデル骨材には， $80 \times 80 \mathrm{~mm}$, $150 \times 150 \mathrm{~mm}$ の菱形，および $\phi 80 \mathrm{~mm}, \phi 150 \mathrm{~mm}$ の円 柱を用いた。 モデル骨材の形状は，川砂利など丸みを持 つ骨材や砕石などの角を持つ骨材の代表例として，それ ぞれ円形と菱形とし，有限要素法による解析が二次元で あることを考虑して柱状とした. また，供試体の大きさ は, 縦は 2 個の $150 \mathrm{~mm}$ の菱形が上下に並べられ，横は 2 個の $80 \mathrm{~mm}$ の菱形が左右に並べられ，さらに骨材間 距離が母材コンクリートの粗骨材最大寸法 $\left(G_{\max }=25\right.$ $\mathrm{mm}$ ）以上となるように配慮した. モデル骨材と母材コ ンクリートの付着面は，モデル骨材の型枠により表面が 滑らかに仕上がるため, 砕石の表面のように凹凸がある ものとは明らかに付着性状が異なると思われる.そこで, モデル骨材の表面に次に示す 2 種類の処置を施した. a 


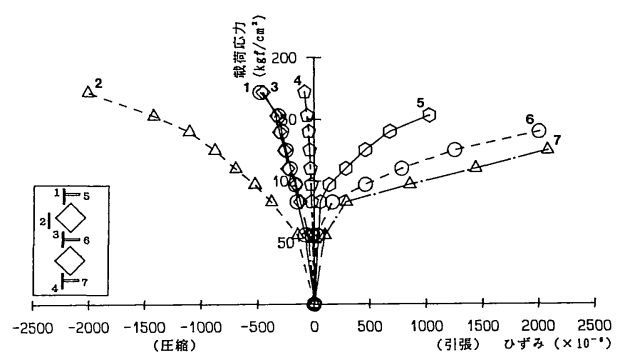

(a ) 縦方向に 2 つの菱形 $80 \times 80 \mathrm{~mm}$ (aシリーズ $)$

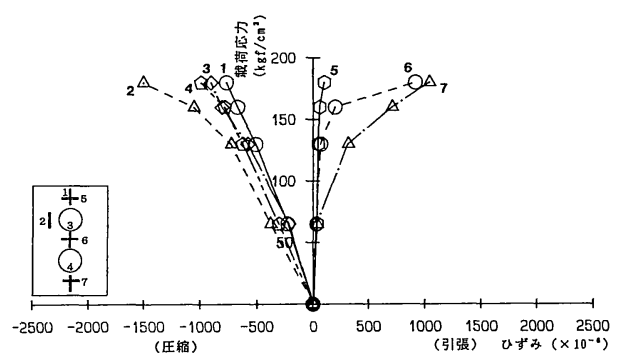

（c）縦方向に 2 つの円柱 $\phi 80 \mathrm{~mm}$ (aシリーズ）

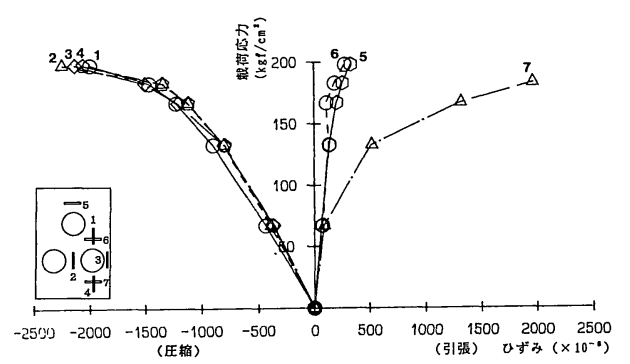

(e ）三角形状の円柱 $\phi 80 \mathrm{~mm}$ (aシリーズ)

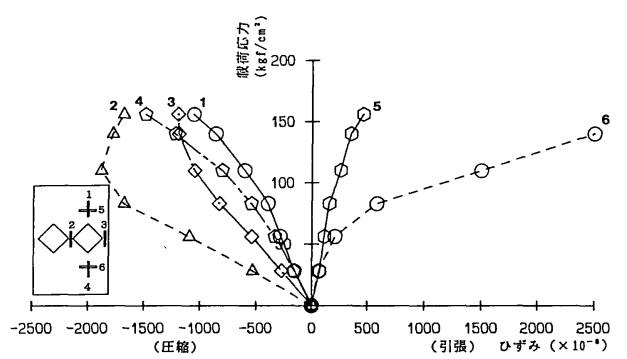

(b) 横方向に 2 つ菱形 $80 \times 80 \mathrm{~mm}$ (aシリーズ)

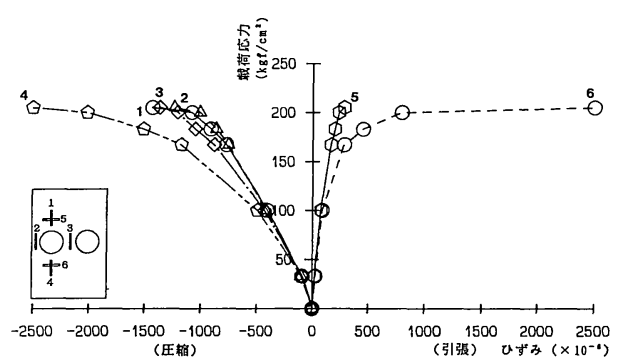

(d) 横方向に 2 つの円柱 $\phi 80 \mathrm{~mm}$ (aシリーズ )

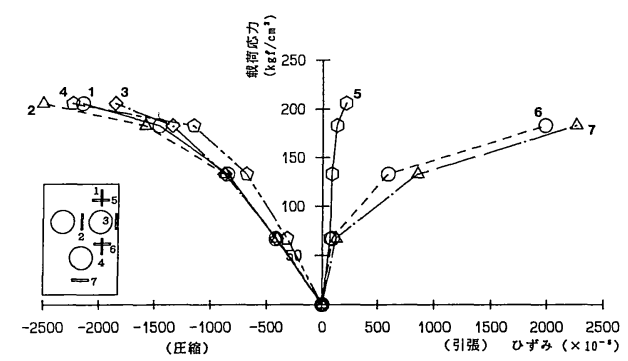

（f）逆三角形状の円柱 $\phi 80 \mathrm{~mm}$ ( $\mathrm{a}$ シリーズ

図一３載荷応力ーひずみ関係

シリーズは，モデル骨材表面に深さ $1 \mathrm{~mm}$ ，幅 $2 \mathrm{~mm}$ で 間隔 $1 \mathrm{~cm}$ ののこぎり歯状の凹凸を付けたもの, $\mathrm{b}$ シリー ズは，モデル骨材表面にのこぎり歯状の凹凸を付け，さ らに実際の骨材より付着を強固にするために，母材コン クリートを打込む前にセメントペーストを塗ったもので ある.なお，母材コンクリートはモデル骨材を所定の位 置に設置した後, 図一1に示す各供試体の上方より打込 まれた。このようにして, モデル骨材の寸法, 形状, 個 数, 配置位置および表面状態を変え, 供試体の数を 21 個とした。

\section{(2) 配 合}

母材コンクリートおよびモデル骨材の配合を表一1に 示す、モデル骨材はモルタル製であるが，モデル骨材が 先に破壊しないように，母材コンクリートおよびモデル 骨材の設計基準強度をそれぞれ $200 \mathrm{kgf} / \mathrm{cm}^{2}, 500$ $\mathrm{kgf} / \mathrm{cm}^{2}$ とした。 セメントはいずれも普通ポルトランド セメントで, 細骨材は揖斐川産で粗粒率 2.61 であり, 粗骨材は天竜川産で粗粒率 6.80 である.なお, 実際の
アーチダムでは単位セメント量が約 $180 \mathrm{~kg} / \mathrm{m}^{3}$, 単位水 量が約 $100 \mathrm{~kg} / \mathrm{m}^{3}$ 程度であるが，ウェットスクリーニン グにより粒径が $25 \mathrm{~mm}$ 以上の粗骨材とその表面に付着 したモルタル分の失われたものが母材コンクリートであ るとすると, 見かけ上単位セメント量と単位水量は増加 する．この点を考慮して母材コンクリートの配合を定め た.

\section{（3）載荷および計測方法}

供試体への載荷は，図一2に示す方向へ $500 \mathrm{tf}$ の耐圧 試験機を用いて行った。 なお，供試体と載荷板の間に端 面拘束の影響を除去するため, グリースを塗布したテフ ロンシートを敷いた。載荷の際に, 載荷荷重と供試体に 貼りつけたストレインゲージによるひずみの計測を行 い,ひびわれ進展状況を観察した。ストレインゲージの 位置は, モデル骨材の上下および側方で, その一例を図 -2 に示す.

\section{（4）実験結果及び考察}

a）モデル骨材周囲のひずみ分布状沉 
図一3に各供試体の載荷応力とひずみの関係のいくつ かの特徴的な例を示す. 図一-3（a ）に示す縦方向に二 つの $\mathrm{a}$ シリーズの $80 \times 80 \mathrm{~mm}$ の菱形のモデル骨材を用 いた供試体では，モデル骨材の上下部の圧縮ひずみが非 常に小さく，圧縮ひずみがほとんど骨材の両側のコンク リートに集中している．その原因としては，上側のモデ ル骨材下部の境界面で上側のモデル骨材と母材コンク リートとがずれを生じ，上側のモデル骨材の下部頂点か ら下側のモデル骨材の上部頂点までにひびわれが発生す ることによって, 下側のモデル骨材の両側のボンドク ラックが上部頂点まで進展し，モデル骨材の上下部に荷 重が鉛直に伝わりにくくなるためと考えられる. 引張ひ ずみについては，上側のモデル骨材上部の引張ひずみが 最も小さいが，2つのモデル骨材の間および下側のモデ ル骨材下部の引張ひずみは, 単一モデル骨材を用いた供 試体のモデル骨材下部の引張ひずみと同様かなり大きな 值を示している. 図一3（b ）に示す横方向に二つの a シリーズの $80 \times 80 \mathrm{~mm}$ の菱形のモデル骨材を用いた供 試体でも, 引張ひずみの分布状況は単一のモデル骨材を 用いた供試体と同じ傾向である.圧縮ひずみについては, モデル骨材下部にある空隙の影響で, モデル骨材下部と 母材コンクリートとの境界面は付着が弱く，モデル骨材 中は荷重が鉛直に伝わりにくくなり，低荷重域ではモデ ル骨材両側の圧縮ひずみが上下部の圧縮ひずみより大き い. そして, 両骨材間の圧縮ひずみは両端部の圧縮ひず みよりさらに大きい. しかし, 高荷重域になると, モデ ル骨材両側のボンドクラックが斜め上方へ母材コンク リートに進展した後，モデル骨材両側に作用している圧 縮応力が骨材の中央部に移動するため, モデル骨材の上 下部の圧縮ひずみが大きくなって，モデル骨材両側の圧 縮ひずみが小さくなることが明らかとなった。

図一3 (c) に示す縦方向に二つの $\mathrm{a}$ シリーズの $\phi 80$ $\mathrm{mm}$ の円柱モデル骨材を用いた供試体では，圧縮ひずみ がモデル骨材の両側に集中するが，その程度が菱形の場 合よりかなり弱くなることが明らかとなった．また，引 張ひずみについても, 菱形の場合よりもかなり小さくな り，モデル骨材下部の空隙の領域が菱形に比較して小さ いことを示している. 図一3（d）に示す横方向に二つ の a シリーズの $\phi 80 \mathrm{~mm}$ の円柱モデル骨材を用いた供 試体では，菱形のモデル骨材を用いた供試体のように， 圧縮ひずみが二つのモデル骨材の中間のコンクリートに 集中しないことが明らかとなった。 また，引張ひずみに ついては, 低荷重域では菱形の場合よりかなり小さい.

図一3 ( e ), ( f ) にそれぞれ, a シリーズの $\phi 80$ $\mathrm{mm}$ 冈柱モデル骨材を三角形の頂点および逆三角形の頂 点に配置した供試体の載荷応力とひずみの関係を示す. モデル骨材の周囲に発生する圧縮ひずみの傾向はいずれ も， $\phi 80 \mathrm{~mm}$ 円柱モデル骨材を 2 個配置した供試体とほ

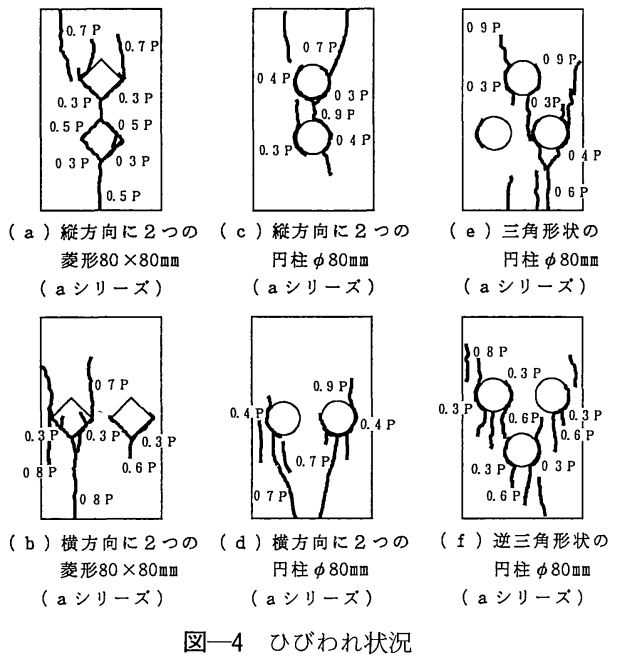

とんど同じである，一方，引張ひずみもモデル骨材が鉛 直方向に配置されていないので, 下側のモデル骨材が上 側のモデル骨材下部の母材コンクリートを拘束せず，モ デル骨材下部の母材コンクリートに大きな引張ひずみが 生じることが明らかとなった。

なお，bシリーズのモデル骨材を用いた供試体は，モ デル骨材と母材コンクリートとの付着が強いため, a シ リーズのモデル骨材を用いた供試体に比べて，全体的に 圧縮ひずみが骨材の両側に集中する傾向が弱く，骨材下 部の引張ひずみが少し小さくなる傾向を示した.

b) ひびわれ状況

図一4に図一3示した供試体のひびわれ状況を示す. なお，ひびわれの進展を示すために，圧縮強度との比率 で表した載荷応力を図中に示す．図一4（a ）に示す縦 方向に a シリーズの二つの $80 \times 80 \mathrm{~mm}$ の菱形のモデル 骨材を用いた供試体では, 低荷重域でモデル骨材の両側 にボンドクラックが発生した. その後，モデル骨材下部 の境界面で母材コンクリートとずれを生じ，骨材下部の 中央から母材コンクリートにひびわれが発生した. 最後 に，上部のモデル骨材の方は両側のボンドクラックが上 部境界面へ少し進展して, 両側のボンドクラックから上 部の母材コンクリートにひびわれが生じた。下部のモデ ル骨材の方は上部のモデル骨材の下部頂点から下部モデ ル骨材の上部頂点までひびわれが進展することによっ て, 両側のボンドクラックが上部境界面の頂点まで進展 した. 図一4（b）に示す横方向にa シリーズの二つの $80 \times 80 \mathrm{~mm}$ の菱形のモデル骨材を用いた供試体では, ひびわれの発生状況は単一モデル骨材を用いた供試体と ほとんど同じであるが，両モデル骨材の外側の端から供 試体の端部までの距離が短いので, 両骨材外側のボンド クラックから斜め上方向へ供試体の端部までひびわれが 生じた. 
表一2 圧縮強度

\begin{tabular}{|c|c|c|c|c|c|}
\hline \multirow{3}{*}{$\begin{array}{l}\text { モテル } \\
\text { 骨材の } \\
\text { 寸法. } \\
\text { 形状 }\end{array}$} & \multirow{3}{*}{$\begin{array}{l}\text { モデル } \\
\text { 骨材の } \\
\text { 配列 }\end{array}$} & \multicolumn{2}{|c|}{ 骨材表面の付着状態 } & \multirow{2}{*}{$\begin{array}{r}P \text { (aシリ } \\
\text { 一 X骨材) } \\
\end{array}$} & \multirow{2}{*}{$\begin{array}{l}P \text { ( } b \text { シリ } \\
\text { 一ズ骨材) }\end{array}$} \\
\hline & & a シリーズ & b シリース & & \\
\hline & & $\begin{array}{c}P \\
\left(k g f / c^{2}\right)\end{array}$ & $\underset{\left(\mathrm{kgf} / \mathrm{ca}^{2}\right)}{\mathrm{P}}$ & 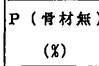 & 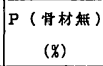 \\
\hline \multirow{6}{*}{$\begin{array}{l}\text { 円柱 } \\
\phi 80 \text { an }\end{array}$} & 0 & 208 & 217 & 97 & 101 \\
\hline & : & 192 & 201 & 89 & 93 \\
\hline & 00 & 207 & 212 & 96 & 99 \\
\hline & : & 199 & $\longrightarrow$ & 93 & 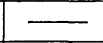 \\
\hline & 응 & 197 & $\longrightarrow$ & 92 & $\longrightarrow$ \\
\hline & 90 & 203 & $\longrightarrow$ & 94 & $\longrightarrow$ \\
\hline \multirow{2}{*}{$\begin{array}{l}\text { 円柱 } \\
\phi 150 \mathrm{an}\end{array}$} & 0 & 191 & 209 & 89 & 97 \\
\hline & :맘 & 175 & 218 & 81 & 101 \\
\hline \multirow{3}{*}{$\begin{array}{c}\text { 菱形 } \\
80 \times 80 \text { an }\end{array}$} & $\Delta$ & 197 & 215 & 92 & 100 \\
\hline & $\begin{array}{l} \\
0 \\
0\end{array}$ & 172 & & 80 & 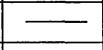 \\
\hline & $\infty$ & 156 & $\longrightarrow$ & 73 & $\longrightarrow$ \\
\hline \multirow{2}{*}{$\begin{array}{l}\text { 蕧形 } \\
150 \times \\
150 \text { a }\end{array}$} & $\infty$ & 154 & 176 & 72 & 82 \\
\hline & $\begin{array}{l}8 \\
0\end{array}$ & 121 & & 56 & \\
\hline 骨材每し & & \multicolumn{2}{|c|}{215} & 100 & 100 \\
\hline
\end{tabular}

図一4（c）に示す縦方向にa シリーズの二つの $\phi 80$ $\mathrm{mm}$ 円柱モデル骨材を用いた供試体では, 初めにモデル 骨材の両側にボンドクラックが発生した. その後, モデ ル骨材下部の境界面で母材コンクリートとずれを生じ, 骨材下部の母材コンクリートにひびわれが発生した. そ れと同時にモデル骨材両側のボンドクラックが上部境界 面へ進展し, モデル骨材上部の母材コンクリートにひび われが生じた. 下部のモデル骨材の方は, 上部のモデル 骨材の下部から下部モデル骨材の上部までひびわれが進 展することによって, 両側のボンドクラックが上部境界 面へ進展した. 最後に, 上部のモデル骨材下部のひびわ れと下部のモデル骨材両側のボンドクラックがつながっ た. 図一4（d）に示す横方向に a シリーズの二つの $\phi$ $80 \mathrm{~mm}$ 円柱モデル骨材を用いた供試体では, 互いの骨 材に面した側 (内側) のボンドクラックより外側のボン ドクラックの方が先に生じた. そして, 両骨材の下部の ひびわれが供試体の下端の中心部へ進展した. 最後に, 骨材外側に生じたボンドクラックから上部へひびわれは 進展したが, 内側のボンドクラックから上部へ進展する ひびわれは，顕著に現れなかった.

図一4 (e ) に示す三つの a シリーズの $\phi 80 \mathrm{~mm}$ 円柱 モデル骨材を三角形の頂点に配置した供武体では, 初め に各モデル骨材両側にボンドクラックが発生し，モデル 骨材と母材コンクリートがずれを生じ骨材下部から下方 へひびわれが進展した. そして，下側のモデル骨材下部 からのびるひびわれが供試体下端にまで進展した. 最後 に, モデル骨材の外側のボンドクラックから供試体の上 方へのびるひびわれが生じた.しかし，内側のボンドク ラックからは，ほとんよ゙ひびわれは進展しなかった．図 -4 (f ) に示す三つの a シリーズの $\phi 80 \mathrm{~mm}$ 円柱モデ
ル骨材を逆三角形の頂点に配置した供試体では, 初めに 各モデル骨材両側にボンドクラックが発生し，モデル骨 材と母材コンクリートがずれを生じ骨材下部から下方へ ひびわれが進展した．そして，モデル骨材両側のボンド クラックからひびわれが下方へ進展し，下側のモデル骨 材のボンドクラックから上方へのびるひびわれは，上側 のモデル骨材へ到達した．最後に，上側のモデル骨材外 側のボンドクラックから上方へのびるひびわれが発生し た. しかし，上側のモデル骨材内側のボンドクラックか ら上方へのびるひびわれは顕著に現れなかった.

なお， b シリーズのモデル骨材を用いた供試体のひび

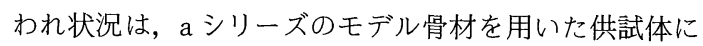
比べて低荷重域でのボンドクラックの発生が少なかった が, 全体のひびわれの傾向にほとんど差は生じなかった.

c）圧縮強度

表一2 に各供試体の圧縮強度を示す，a シリーズのモ デル骨材を用い，モデル骨材と母材コンクリートとの境 界面の付着が弱い供試体は, モデル骨材のない供試体に 比べて, 明らかに圧縮強度が低下している. 低下の割合 は, $\phi 80 \mathrm{~mm}$ の円柱, $\phi 150 \mathrm{~mm}$ の円柱, $80 \times 80 \mathrm{~mm}$ の 菱形, $150 \times 150 \mathrm{~mm}$ の菱形のモデル骨材を用いた供試 体の順に大きくなる．これは，円柱のモデル骨材を用い た供試体のような骨材下部の円周の境界面にある空隙に 対して, 菱形のモデル骨材を用いた供試体のような骨材 下部の 45 度の傾きを持つ境界面にある空陌の方が，よ りコンクリートの圧縮強度に及ぼす影響が強いためと考 えられる. また, 骨材の寸法の増加に伴い, 骨材の下部 にある空隙の長さも増加し, 供試体の圧縮強度に及ぼす 影響が強くなるためと考えられる.さらに, 同じ形状, 同じ大きさのモデル骨材を用いた供試体では，モデル骨 材の個数の増加に伴い, 明らかに供試体の圧縮強度が低 下している.これは, モデル骨材の個数の増加に伴い, 供武体の中に空隙の量が増加し，各モデル骨材の下部に ある空隙によって生じるひびわれがつながって, 供試体 が早く破壊するためと考えられる.

b シリーズのモデル骨材を用い, モデル骨材と母材コ ンクリートとの境界面の付着が強い供試体の場合では, 円柱及び $80 \times 80 \mathrm{~mm}$ の菱形のモデル骨材を用いた供試 体は，圧縮強度がほとんどモデル骨材の影響を受けてい ない.これは，bリーズのモデル骨材を用いた供試体の 場合では，モデル骨材と母材コンクリートとの境界面の 付着が強いため, 低荷重域でモデル骨材の両側のボンド クラックおよび下部の境界面における母材コンクリート とのずれが発生せず，モデル骨材のない場合とほとんど 同じ挙動を示したためと考えられる．しかし，150×150 $\mathrm{mm}$ の菱形のモデル骨材を用いた供試体は，モデル骨材 と母材コンクリートとの境界面の付着が強くなり，154 $\mathrm{kgf} / \mathrm{cm}^{2}$ から $176 \mathrm{kgf} / \mathrm{cm}^{2}$ へと圧縮強度は大きくなる 


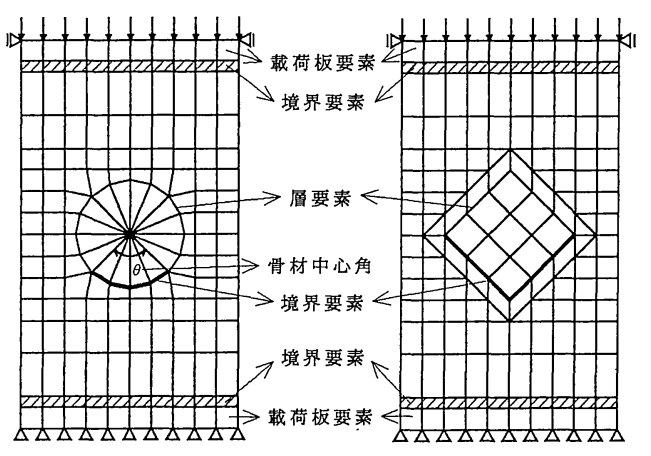

図一5 解析モデル

が, モデル骨材のない場合の圧縮強度の約 $80 \%$ にすぎ ない。これは，150×150 mm の菱形のモデル骨材を用 いた供試体の場合では, $80 \times 80 \mathrm{~mm}$ の菱形のモデル骨 材を用いた供試体より, モデル骨材下部の空隙が長く, モデル骨材下部の境界面に作用するせん断力も大きいの で, モデル骨材と母材コンクリートとの境界面の付着が 強くなったにもかかわらず，モデル骨材の両側のボンド クラックおよび下部の境界面における母材コンクリート とのずれが早く発生したためと考えられる.

\section{3. 解 析}

\section{(1) 解析の概要}

実験を行った供試体について有限要素法による解析を 行い, 実験結果を検証することを目的とした，解析に用 いた有限要素法の解析プログラムは, 前川ら ${ }^{16)}$ によって 開発されたものである.このプログラムでは，ひびわれ は各要素ごとに最大主応力がコンクリートの引張強度に 達すると, 最大主応力方向に垂直に発生すると仮定し, ひびわれ発生後はその要素における最大主応力方向の剛 性を零として剛性マトリックスを修正し, 逐次計算を行 うことにより解を求めている. 解析モデルは図—5に示 すように，供試体と載荷板の間に載荷板による拘束を表 す境界要素, モデル骨材下部の空隙を表す境界要素,さ らにそれ以外の境界面に, モデル骨材と母材コンクリー トとの付着状態を表すために，ヤング係数を母材コンク リートより小さくした層要素を用いて解析を行った。な お，境界要素は摩擦によるせん断伝達を表すことができ る.境界要素に作用する摩擦力をプログラムでは,式 ( 1 ) ，（2）のように表すことにした.

供試体と載荷板の間において,

摩擦力 $=A \times$ 圧縮力

モデル骨材下部の空隙の部分において,

$$
\text { 摩擦力 }=\left\{\begin{array}{ll}
B \times \text { 圧縮力 } & (\text { 圧縮ひずみ } \geqq 0) \\
0 & (\text { 圧縮ひずみ }<0)
\end{array} \cdots\right.
$$

係数 $A$ は, 供試体と載荷板の間が摩擦を伴い滑べる 場合の摩擦係数である. 本解析では, モデル骨材を持た

\begin{tabular}{|c|c|c|c|}
\hline \multirow{2}{*}{ 解析要素 } & \multirow{2}{*}{ 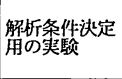 } & \multicolumn{2}{|c|}{ 裸数モデル骨材の奜駗 } \\
\hline & & a シリーズ骨材 & bシリーズ骨材 \\
\hline 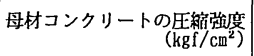 & 215 & 215 & 215 \\
\hline 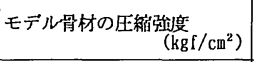 & 500 & 500 & 500 \\
\hline 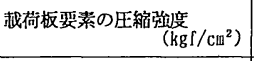 & 5000 & 5000 & 5000 \\
\hline 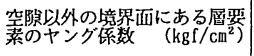 & 1. $5 \times 10^{5}$ & 1. $5 \times 10^{5}$ & 1. $8 \times 10^{5}$ \\
\hline 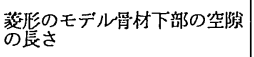 & & $\begin{array}{l}\text { モデル顝愖の } \\
\text { 卡部 }\end{array}$ & $\begin{array}{l}\text { モデル骨栻の } \\
\text { 卡部の全 }\end{array}$ \\
\hline 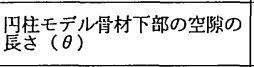 & $\begin{array}{l}60^{\circ} \\
135^{\circ}\end{array}$ & $90^{\circ}$ & $90^{\circ}$ \\
\hline 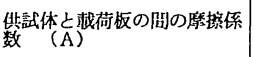 & 0.3 & 0.3 & 0.3 \\
\hline 境界面の摩㨲係数 （B） & 0.15 & 0.15 & 0.3 \\
\hline
\end{tabular}

ない供試体において, 載荷板の拘束が供試体のひずみ分 布に与える影響に対する実験結果と解析結果との比較に よって, 0.3 に決定した. 一方, 係数 $B$ は, モデル骨 材下部の空隙部分の境界面が摩擦を伴い滑べる場合の摩 擦係数である.この係数は, 実験におけるモデル骨材の 表面状態およびモデル骨材下部の空隙部分の付着状態に よって決定される.なお, 空隙を表す境界要素の長さは, 菱形のモデル骨材の場合は下部の 2 辺の長さとし, 円柱 のモデル骨材の場合は図—5に示すように，骨材の中心 角 $\theta$ で表すこととした。

\section{（2）解析条件の決定}

\section{a) 実験方法}

本解析プログラムを用いて実験結果を解析するにあた り，特に円柱のモデル骨材下部の空隙の長さを定める必 要がある. そこで, 中央に $\phi 150 \mathrm{~mm}$ の円柱の単一モデ ル骨材を配置した $50 \times 30 \times 12 \mathrm{~cm}$ の直方体の供試体を $2 つ$ 作製し, 載荷実験を行った。なお, これらの供試体 はモデル骨材下部の表面に, 骨材の中心角 $\theta$ がそれぞ れ $60^{\circ}$ よ $135^{\circ}$ の範囲でグリーズを塗布し, 空隙の長さ を特定したものである. モデル骨材のそれ以外の表面に は，のこぎり歯状の凹凸を付けた．母材コンクリートお よびモデル骨材の配合は表一 2 に示すように, 複数モデ ル骨材の実験之同じである.また載荷方法も同じである.

\section{b) 解析方法}

表一3に解析条件を示す. 母材コンクリートおよびモ デル骨材の圧縮強度はそれぞれの実験值を, またヤング 係数は, 応力ーひずみ関係を二次曲線と仮定し，その接 線を゙ング係数とした. 空隙以外のモデル骨材と母材コ ンクリートとの境界面にある層要素のヤング係数は, $1.5 \times 10^{5} \mathrm{kgf} / \mathrm{cm}^{2}$ を用いた。 さらに，モデル骨材下部に おける境界要素の摩擦係数 B は, 実験において空隙の部 分の表面にグリースを塗布したが，摩擦が完全にはなく ならないことを考慮して 0.15 とした. 


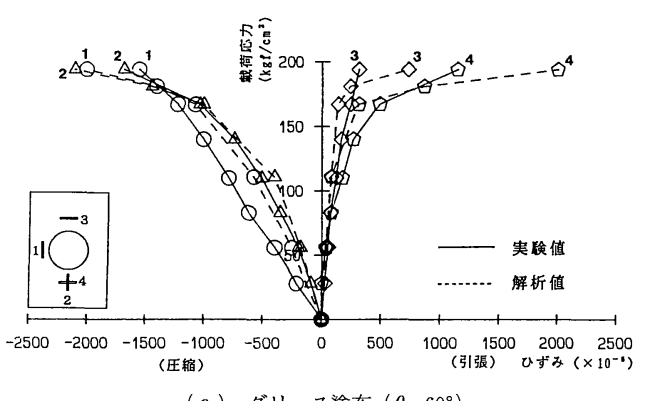

(a) グリース塗布 $\left(\theta=60^{\circ}\right)$

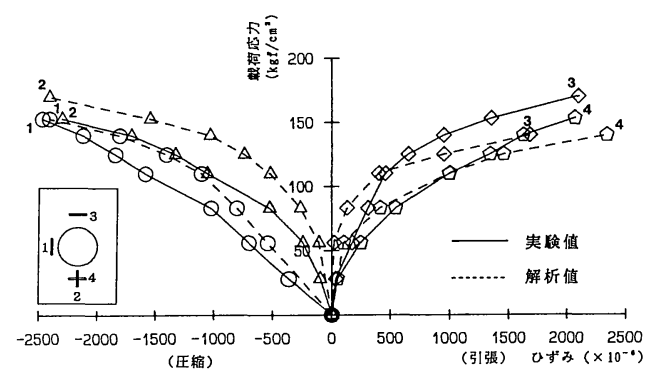

(b) グリース塗布 $\left(\theta=135^{\circ}\right)$

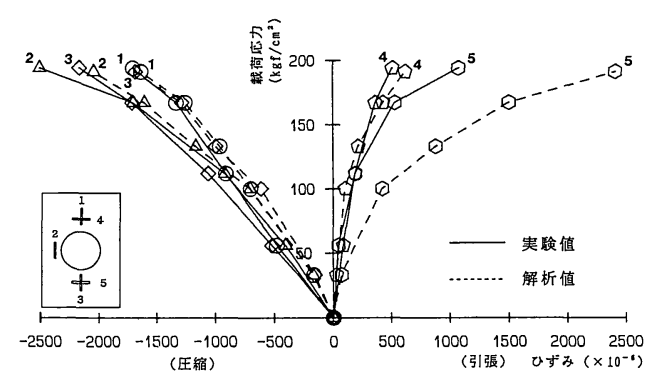

(c) グリース塗布せず

図一～載荷応力ーひずみ関係（円柱 $\phi 150 \mathrm{~mm}$ )

c）実験結果と解析結果との比較

図一6 ( a ), (b ) に, それぞれ骨材の中心角 $\theta=60^{\circ}$, $135^{\circ}$ の範囲でグリースを塗布した供試体の載荷応力と ひずみの関係の実験值と解析值との比較を示す. $\theta=$ $135^{\circ}$ の範囲でグリースを塗布した供試体は， $\theta=60^{\circ}$ の 範囲でグリースを塗布した供試体に比べて，圧縮ひずみ がモデル骨材の両側のコンクリートに集中し，モデル骨 材の下部に大きな引張ひずみが生じることが実験結果と 解析結果で一致した。 また，図一7 ( a )，( b ) にこれ ら 2 つ供試体の実験および解析で得られたひびわれ状 況の比較を示す.この図においても， $\theta=60^{\circ}$ の範囲で グリースを塗布した供試体と $\theta=135^{\circ}$ の範囲でグリース を塗布した供試体のいずれも，ひびわれの発生位置およ び分布状況が実験結果と解析結果でほとんど一致した。 さらに, 表一 4 に 2 つ供試体の実験および解析で得ら れた圧縮強度の比較を示す. 解析における圧縮強度は, 支点反力が最大值に至る時の荷重より求めた. 表に示す ように，骨材の中心角 $\theta=135^{\circ}$ の範囲でグリースを塗布

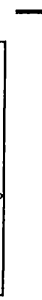

( a ) グリース塗布 $\left(\theta=60^{\circ}\right)$
実験ひびわれ

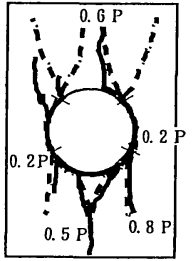
$\left(\phi=135^{\circ}\right)$ (b) グリース塗布

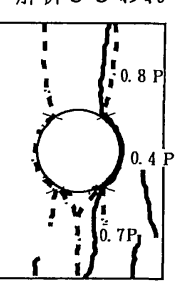

(c) グリース塗布 せず
図一7ひびわれ状況（円柱 $\phi 150 \mathrm{~mm}$ )

表一4 圧縮強度（円柱 $\phi 150 \mathrm{~mm}$ )

\begin{tabular}{|c|c|c|c|}
\hline $\begin{array}{l}\text { グリースを盜布した } \\
\text { 骨材の中心角 } \theta\end{array}$ & 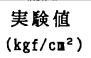 & $\begin{array}{l}\text { 解析值 } \\
\left(\mathrm{kgf} / \mathrm{ca}^{2}\right)\end{array}$ & $\frac{\text { 実硂值 }}{\text { 解析值 }}$ \\
\hline $135^{\circ}$ & 170 & 181 & 0.94 \\
\hline $60^{\circ}$ & 207 & 208 & 0.99 \\
\hline クリリースを望布せず & 191 & 189 & 1. 01 \\
\hline
\end{tabular}

した供試体は， $\theta=60^{\circ}$ の範囲でグリースを塗布した供 試体に比べ, 明らかに圧縮強度が低下することが実験結 果と解析結果で一致した.

d) 中心角 $\theta$ および摩擦係数 $B$ の決定

図一1に示す複数モデル骨材の実験において得られた 中央に a シリーズの $\phi 150 \mathrm{~mm}$ の円柱の単一モデル骨材 を配置した供試体の載荷応力とひずみの関係，ひびわれ 状況および圧縮強度をこれら $2 つ$ 供試体と比較し，中 心角 $\theta$ を定めることにした．図一6に示すように，モデ ル骨材下部の表面を処理しない場合の載荷応力とひずみ の関係は， $\theta=60^{\circ}$ の範囲でグリースを塗布した供試体 の載荷応力とひずみの関係にほとんど一致している。一 方, 図一7に示すひびわれ状況においては, ボンドクラッ クがモデル骨材の上部へ達している点で, $\theta=135^{\circ}$ のグ リースを塗布した供試体のひびわれ状況に近いと思われ る.さらに表一 4 に示すように, 圧縮強度においては $\theta$ $=60^{\circ}$ と $\theta=135^{\circ}$ の範囲でグリースを塗布した供試体の 圧縮強度のほとんど中間の值を示している.このように, グリースを塗布しない場合の挙動が, $\theta=60^{\circ}$ と $\theta=135^{\circ}$ の範囲でグリースを塗布した場合の挙動の中間を示した ことから，表一2に示す配合の母材コンクリートでは， ブリージングの影響によりほとんど摩擦がなくなる程度 の空隙が，およそ中心角 $\theta=90^{\circ}$ の範囲で骨材下部に生 じていることが明らかとなった.したがって，複数モデ ル骨材の実験における円柱のモデル骨材下部の空隙の長 さは, 解析では中心角を $\theta=90^{\circ}$ と仮定することにした. また，モデル骨材下部における境界要素の摩擦係数 $B$ は，グリースを塗布した場合と同様，0.15を用いるこ とにした。なお，検証のためこの条件で解析を行った結 果, 図一 6 ( c ), 図一7 (c ) および表一4に示すように, いずれも解析值は実験值とほとんど同じ傾向を示した. 


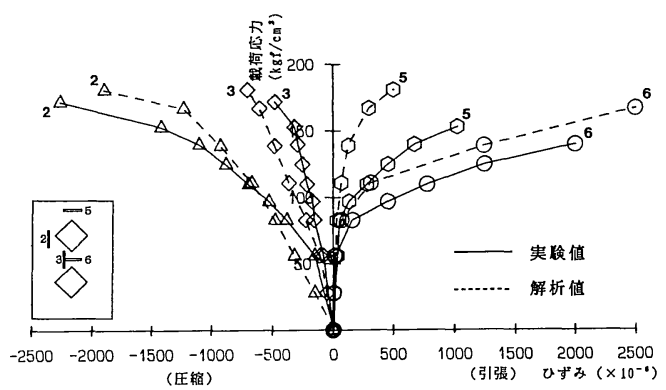

(a) 縦方向に 2 つ菱形 $80 \times 80 \mathrm{~mm}$ (aシリーズ $)$

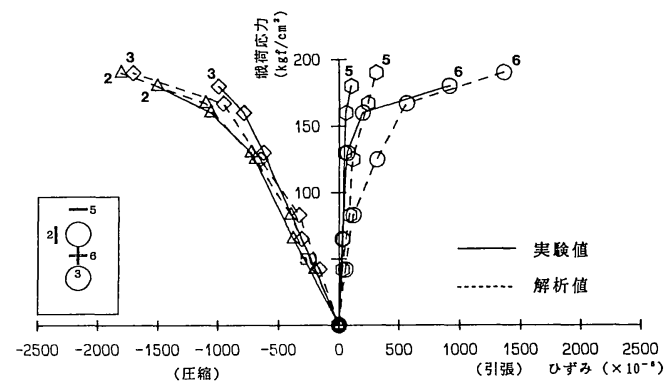

(c) 綐方向に 2 つの円柱 $\phi 80 \mathrm{~mm}$ ( $\mathrm{a}$ シリーズ)

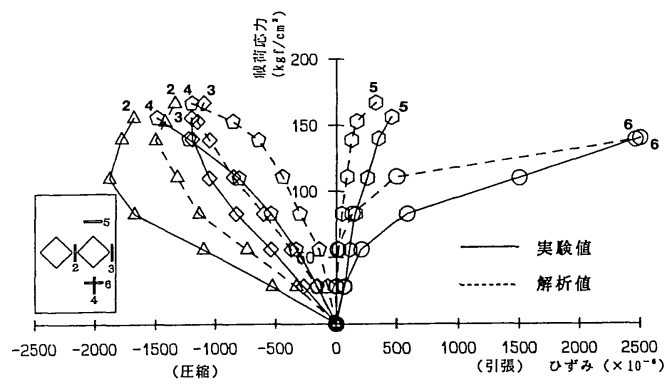

(b) 横方向に 2 つの菱形 $80 \times 80 \mathrm{~mm}$ (aシリーズ $)$

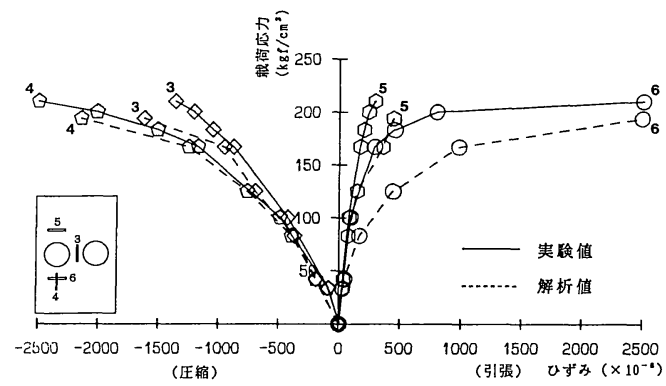

(d) 横方向に 2 つの円柱 $\phi 80 \mathrm{~mm}$ (aシリーズ $)$

図一8 載荷応力-ひずみ関係 (実験と解析の比較)

\section{（3）複数モデル骨材供試体の解析}

a) 解析条件

表一 3 に本解析で用いた解析条件を示す。 a シリーズ の骨材を用いた場合は, 空隙以外の境界面にある層要素 のヤング係数, 円柱モデル骨材下部の空隙の長さ, およ び空隙の境界面の摩擦係数 Bについて, 前節で述べた解 析と同様の值を用いた。しかし， b シリーズの骨材を用 いた場合は，モデル骨材と母材コンクリートとの付着が 強いことを考慮して, 空隙以外の境界面にある層要素の ヤング係数を $1.5 \times 10^{5} \mathrm{kgf} / \mathrm{cm}^{2}$ から $1.8 \times 10^{5} \mathrm{kgf} / \mathrm{cm}^{2}$ へ, また空隙の境界面の摩擦係数 $B$ を 0.15 から 2 倍の 0.3 へ増加させた。 なお， 円柱モデル骨材下部の空隙の 長さは変化させていない．このような解析条件を用いて 解析を行った.

b）実験結果と解析結果との比較

例として, 縦方向および横方向に 2 つの a シリーズの $80 \times 80 \mathrm{~mm}$ の菱形および $\phi 80 \mathrm{~mm}$ の円柱モデル骨材を 用いた供試体の場合を示す.

(1) 載荷応力とひずみ関係

図一8（a）に示す縦方向に二つの a シリーズの $80 \times$ $80 \mathrm{~mm}$ の菱形のモデル骨材を用いた供試体の場合では, モデル骨材上下部の圧縮ひずみが非常に小さく, 圧縮ひ ずみがほとんビ骨材の両側の母材コンクリートに集中す ること，およびモデル骨材の下部の母材コンクリートに 大きな引張ひずみが生じることは, 解析結果と実験結果 で一致した。 また，モデル骨材の上部の引張ひずみにつ
いては，実験値より解析値の方が少し小さい。これは， 解析の場合では，モデル骨材の上部の境界面の付着が実 際の状態より少し強く, モデル骨材の両側のボンドク ラックが上部の境界面へ進展しにくくなるためと考えら れる. 図一8（b ）に示す横方向に二つの a シリーズの $80 \times 80 \mathrm{~mm}$ の菱形のモデル骨材を用いた供試体の場合 では, 低荷重域で, 圧縮ひずみが骨材の両側, 特に両骨 材間の母材コンクリートに集中し, 高荷重域になると, モデル骨材の両側の応力集中による大きな圧縮ひずみの 戻りが生じることは, 実験結果と共に解析的にも明らか となった。 そして，モデル骨材の上下部の引張ひずみの 分布も解析結果と実駼結果でほとんど一致した.

図一8（c）に示す縦方向に二つの a シリーズの $\phi 80$ $\mathrm{mm}$ の円柱モデル骨材を用いた供試体の場合では, 菱形 のモデル骨材を用いた供試体より，圧縮ひずみが骨材の 両側の母材コンクリートに集中しないことは, 実験結果 と共に解析結果においても, その傾向が認められた。 そ して, 骨材の上下部の引張ひずみの分布も解析結果と実 験結果で一致した. 図一8（d）に示す横方向に二つの a シリーズの $\phi 80 \mathrm{~mm}$ の円柱モデル骨材を用いた供試 体の場合では，菱形のモデル骨材を用いた供試体より， 圧縮ひずみが両骨材間の母材コンクリートに集中しない ことは，実験結果と共に解析結果においても，之の傾向 が認められた。 また，モデル骨材の下部の引張ひずみに ついては, 実験值より解析値の方が少し大きい.これは, 解析の場合では，モデル骨材の下部にある空隙を表す境 


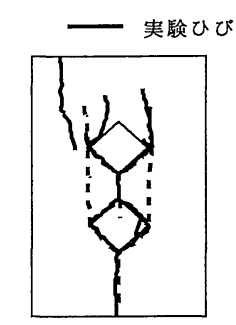

(a) 縦方向に 2 つの 蒙形 $80 \times 80 \mathrm{~mm}$ ( aシリーズ)

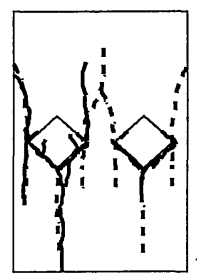

(b) 横方向に 2 つの 菱形 $80 \times 80$ mm ( aシリーズ)
表一5 圧縮強度（実験と解析の比較）

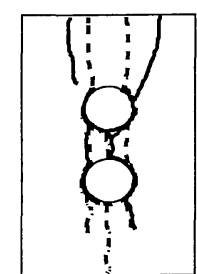

(c) 繸方向に 2 つの 円柱 $\phi 80 \mathrm{~mm}$

( a シリーズ)

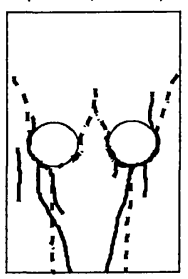

(d) 横方向に $2 \supset 0$ 円柱 $\phi 80 \mathrm{~mm}$ ( $\mathrm{a}$ シリーズ)
図一9 ひびわれ状況（実験と解析の比較）

\begin{tabular}{|c|c|c|c|c|c|c|c|}
\hline \multirow{4}{*}{$\begin{array}{l}モ テ ゙ ル \\
\text { 骨材の } \\
\text { 寸法・ } \\
\text { 形状 }\end{array}$} & \multirow{4}{*}{$\begin{array}{l}\text { モテル } \\
\text { 骨材の } \\
\text { 配列 }\end{array}$} & \multicolumn{6}{|c|}{ 骨材表面の付着条件 } \\
\hline & & \multicolumn{3}{|c|}{$\mathrm{a} シ リ ー ス\left(\mathrm{kgf} / \mathrm{cm}^{2}\right)$} & \multicolumn{3}{|c|}{$\mathrm{b}$ シリース $\left(\mathrm{kgf} / \mathrm{cm}^{2}\right)$} \\
\hline & & 実跧值 & 解析值 & $\mathrm{p} 1$ & 実焕值 & 解析值 & p 1 \\
\hline & & p 1 & $\mathrm{p} 2$ & $\mathrm{p} 2$ & p 1 & p 2 & $\mathrm{p} 2$ \\
\hline \multirow{6}{*}{$\begin{array}{c}\text { 円柱 } \\
\phi 80 \text { mा }\end{array}$} & 0 & 208 & $\begin{array}{lll}2 & 0 & 2\end{array}$ & 1.03 & 217 & 210 & 1.03 \\
\hline & \begin{tabular}{|l|} 
\\
0 \\
\end{tabular} & 192 & 186 & 1.03 & 201 & 210 & 0.96 \\
\hline & 00 & 207 & 194 & 1.07 & 212 & 2114 & 0.99 \\
\hline & \begin{tabular}{|l}
8 \\
0
\end{tabular} & 199 & 175 & 1.14 & - & - & - \\
\hline & 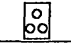 & 197 & 181 & 1.09 & 一 & - & - \\
\hline & 90 & 203 & 1888 & 1.08 & - & - & - \\
\hline \multirow{2}{*}{$\begin{array}{c}\text { 円柱 } \\
\phi 150 \mathrm{mu}\end{array}$} & 0 & 191 & 189 & 1.01 & 209 & 208 & 1.00 \\
\hline & : & 175 & $\begin{array}{lll}1 & 6 & 0 \\
\end{array}$ & 1.09 & 218 & 210 & 1.04 \\
\hline \multirow{3}{*}{$\begin{array}{c}\text { 蕧形 } \\
0 \times 80 \mathrm{ma}\end{array}$} & 0 & 197 & 194 & 1.02 & 215 & 208 & 1.03 \\
\hline & \begin{tabular}{|l|} 
\\
0 \\
\end{tabular} & 172 & 180 & 0.96 & - & - & - \\
\hline & $\infty$ & 156 & 165 & 0.95 & - & - & - \\
\hline \multirow{2}{*}{$\begin{array}{c}\text { 菱形 } \\
150 \times \\
150 \text { षu }\end{array}$} & 0 & 154 & 166 & 0.93 & 176 & 166 & 1.06 \\
\hline & 8 & 121 & 125 & 0.97 & - & - & - \\
\hline 材無し & & 215 & 218 & 0.99 & - & - & - \\
\hline
\end{tabular}

界面の付着が実際の状態より少し弱く，モデル骨材の下 部境界面において低荷重域でモデル骨材と母材コンク リートとがずれを生じるためと考えられる.

(2) ひびわれ状況

図一9（a ）に示す縦方向に二つの a シリーズの $80 x$ $80 \mathrm{~mm}$ の菱形のモデル骨材を用いた供試体の場合では, 特に下部のモデル骨材において, 上部のモデル骨材の下 部頂点から下部のモデル骨材の上部頂点までにひびわれ が発生することによって, 両側のボンドクラックが上部 境界面の頂点まで進展する傾向が, 解析結果と実験結果 で一致した. 図一9（b ）に示す横方向に二つの a シリー ズの $80 \times 80 \mathrm{~mm}$ の菱形のモデル骨材を用いた供試体の 場合では，骨材の両側のボンドクラックからのひびわれ の進展状況，および骨材の下部頂点から下方へのひびわ れの進展状況が，解析結果と実験結果で一致した。

図一9（c）に示す縦方向に二つの a シリーズの $\phi 80$ $\mathrm{mm}$ の円柱モデル骨材を用いた供試体の場合では, 特に 下部のモデル骨材において，上部のモデル骨材の下部か ら下部のモデル骨材の上部までひびわれが進展すること によって, 両側のボンドクラックが上部境界面へ進展し, 最後に, 上部のモデル骨材下部のひびわれと下部のモデ ル骨材両側のボンドクラックがつながる状況が, 解析結 果と実験結果で一致した．図一9（d）に示す横方向に 二つの a シリーズの $\phi 80 \mathrm{~mm}$ の円柱モデル骨材を用い た供試体の場合では，モデル骨材の下部にある空隙に よって生じるひびわれの傾向，およびモデル骨材の内側 よりむしろ外側のボンドクラックから上部の母材コンク リートにひびわれが進展する傾向が, 解析結果と実験結
果で一致した.

(3) 圧縮強度

表一 5 に各供試体の圧縮強度の解析值と実験値との比 較を示す. a シリーズのモデル骨材と母材コンクリート との境界面の付着状態が弱い供試体は，モデル骨材を持 たない供試体に比べて圧縮強度が低下し，その低下の割 合は $\phi 80 \mathrm{~mm}$ の円柱, $\phi 150 \mathrm{~mm}$ の円柱, $80 \times 80 \mathrm{~mm}$ の 菱形， $150 \times 150 \mathrm{~mm}$ の菱形のモデル骨材を用いた供試 体の順で大きくなることは解析的にも明らかとなった。 そして, 同じ寸法, 形状のモデル骨材を用いた供試体で は, モデル骨材の個数の増加に伴い, 供試体の圧縮強度 が低下することも解析結果と実験結果で一致した.また， $\mathrm{b}$ シリーズのモデル骨材と母材コンクリートとの境界面 の付着状態が強い供試体では, 円柱及び $80 \times 80 \mathrm{~mm}$ の 菱形のモデル骨材を用いた供試体は圧縮強度がほとんど モデル骨材の影響を受けないが， $150 \times 150 \mathrm{~mm}$ の菱形 のモデル骨材を用いた供試体は, 明らかに圧縮強度が低 下することは解析結果と実験結果で一致した。

\section{4. 結 論}

本研究で得られた結果を要約すると，以下のようにな る.

（1）単一のモデル骨材を用いた供試体に対して, 複 数のモデル骨材を用いた供試体の場合では，モデル骨材 の個数の増加に伴い, 各モデル骨材の下部にある空隙に よって生じるひびわれがつながり, 供試体の圧縮強度が 低下する. そして，その低下の割合は， $\phi 80 \mathrm{~mm}$ の円柱, $\phi 150 \mathrm{~mm}$ の円柱, $80 \mathrm{~mm} \times 80 \mathrm{~mm}$ の菱形, $150 \mathrm{~mm} \times$ 
$150 \mathrm{~mm}$ の菱形のモデル骨材を用いた供試体の順に大き くなることが実験および解析により明らかとなった。こ れは，実際のダムコンクリートにおいて， $G_{\max }$ が 150 $\mathrm{mm}$ 程度の骨材を使用することによる圧縮強度の低下を 示しており, 特に砕石による低下の割合が大きいことを 示唆している. またウェットスクリーニングによって $G_{\max }$ の大きい粗骨材を除いて圧縮強度試験を行うこと は，実際の圧縮強度を過大評価する可能性があることも 示していると言えよう.

（2）円柱のモデル骨材を用いた供試体に比べて，菱 形のモデル骨材を用いた供試体のように骨材下部の $45^{\circ}$ の傾きを持つ境界面にある空隙の方が，コンクリートの 圧縮強度低下に及ぼす影響が大きいことが実験および解 析により明らかとなった。

（３）ブリージングによって円柱のモデル骨材下部に 生じる空陌は, 中心角 $\theta=90^{\circ}$ 程度の範囲であり, 骨材 表面にグリースを塗布した状態と同様のほとんど母材コ ンクリートと摩擦がない程度の空陌となることが, 実験 と解析により判明した。

（4）本研究で用いた有限要素解析手法により, 複数 モデル骨材を用いた供試体に対して，ブリージングによ るモデル骨材下部の空隙がひびわれ性状や圧縮強度に及 ぼす影響を十分な精度で予測することが可能となった。

\section{参 考 文 献}

1）岩崎訓明・富山泰全：セメントペースト一骨材界面の結 合・破壊機構と強度, セメント技術年報, 第 30 巻, pp. $354 \sim 357,1976$ 年.

2）鈴木鈨也・富山泰全：骨材とペーストの付着について, セメント技術年報，第 30 巻，pp. 351 353，1976 年.

3）川上英男・岡田徳一：骨材岩質が付着性状及びモルタル 強度に及ぼす影響, セメント技術年報, 第 37 巻, pp. 120 123, 1983 年.

4）森野奎二・山口典良・内藤幸雄 : 各種岩石骨材とセメン トペーストとの付着性状：コンクリート工学年次講演会 講演論文集, 第 2 巻, pp. 93 96, 1980 年.

5）爾見軍治・嶋谷宏文：コンクリート用骨材の破砕値とコ
ンクリートの強度, セメントコンクリート, 第 235 号, 1966 年 9 月.

6）爾見軍治・嶋谷宏文：骨材の強度とコンクリート強度の 関連について, セメント技術年報, 第 21 巻, pp. 321 325, 1967 年.

7）枷場重正・宮北 啓・斎藤 満・佐伯繁樹：コンクリー 卜の破壊機構に関する基礎的研究，セメント技術年報, 第 28 巻, pp. 197 201，1974 年.

8）枷場重正・斎藤 満・宮北 啓・今井 悟：コンクリー 卜の破壞機構に関する基礎的研究, セメント技術年報, 第 30 巻, pp. 366 369, 1976 年.

9）小阪義夫 · 谷川恭雄・太田福男：モデル骨材コンクリー トの力学性質におよぼす粗骨材間隔の影響, セメント技 術年報, 第 27 巻, pp. 212 216, 1973 年.

10）小阪義夫・谷川恭雄・太田福男 : 各種の骨材を用いたコ ンクリートの力学特性, セメント技術年報, 第 27 巻, pp. 238 242, 1973 年.

11）小阪義夫・谷川恭雄・太田福男：コンクリートの破壊挙 動におよぼす粗骨材の影響（第 1 報：モデル解析法によ る検討), 日本建築学会論文報告集, 第 228 号, pp. 1 11, 1975 年 2 月.

12）小阪義夫・谷川恭雄：コンクリートの破壊挙動におよぼ す粗骨材の影響（第 2 報：マイクロクラック観察法によ る検討), 日本建築学会論文報告集, 第 231 号, pp. 1 11, 1975 年 5 月.

13）田沢栄一・南 和孝・岡本修一・西川 毅：ブリージン グを想定したモデルコンクリートの圧縮破壊性状，コン クリート工学年次論文報告集, 第 9 巻 1 号, pp. 133 138, 1987 年.

14）安藤兼治・杉本忠男・梅原秀哲・吉田弥智：ダム用コン クリートの強度特性に及ぼす粗骨材の影響, コンクリー 卜工学年次論文報告集, 第 11 巻 1 号, pp. 41 46, 1989 年.

15）安藤兼治・張 剣・梅原秀哲・吉田弥智：粗骨材がダム 用コンクリート強度特性に及ぼす影響, コンクリート工 学年次論文報告集, 第 12 巻 1 号, pp. 721 726, 1990 年.

16）前川宏一：鉄筋コンクリート用解析プログラム「COMM $2 」$, 第 2 回 RC 構造のせん断問題に対する解析的研究に 関するコロキウム論文集, pp. 79 86, 1983 年 10 月.

(1992. 2.3 受付)

\section{EFFECTS OF COARSE AGGREGATE ON COMPRESSIVE STRENGTH OF DAM CONCRETE}

Hidetaka UMEHARA, Jian ZHANG, Minoru UEDA and Hirotomo YOSHIDA

The effects of the voids caused by bleeding under the bottom of coarse aggregates to the mechanical behavior such as cracks and compressive strengths were investigated in dam concrete with coarse aggregates of less than $150 \mathrm{~mm}$ of maximum size. Rectangular concrete specimens which have several model aggregates made by mortar with the shape of circle and rhombus were tested in order to grasp the behavior of cracks and compressive strengths. In addition to the experimental study, the analysis using finite element method also was conducted for verifying the results of experiments. It has been cleared that the voids under the aggregates of large size deteriorate the compressive strengths in dam concrete greatly. 